\title{
再発性性器ヘルペス患者の治療実態に関するアンケート調査 〜患者ニーズと医師（皮膚科，婦人科および泌尿器科）の診療実態〜
}

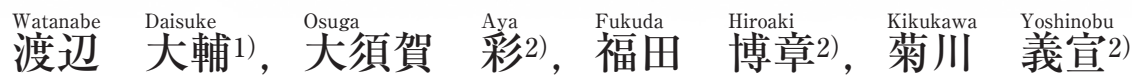

要 旨

再発性性器ヘルペス（recurrent genital herpes：RGH）患者232名と，皮膚科，婦人科・ 産婦人科 (以下, 婦人科), 泌尿器科の医師 231 名を対象に, RGHの患者ニーズおよび医 師の診療実態に関するアンケート調査を行った。

回答を得た患者の男女比は6：4で，再発頻度が年1〜2回の患者が8割を占めた。患者全体 の6割が内服抗ウイルス薬（以下，内服薬）を単独または併用で使用していたのに対し，3 割は外用抗ウイルス薬（以下, 外用薬）のみで治療していると回答した。現在の治療を「満 足」とした患者は，Patient Initiated Therapy（以下，PIT）で44.6\%，5日間投与で $31.1 \%$,

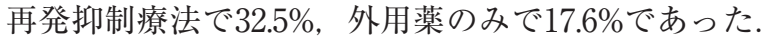

診断にウイルス抗体検査を用いると回答した医師のうち, 受診時の皮疹におけるウイルス の有無を判断する目的で抗体検査を実施すると回答した医師は, 婦人科および泌尿器科で 半数を超えた.

RGH診療で重視することは患者と医師で大きく異なり, 最も差が大きかった項目は「再 発をなくす」(患者 $38.8 \%$ ：医師16.9\%) であった。

本調査の結果, 日本性感染症学会等の診療ガイドラインで推奨されている内服治療が治療 の中心であったものの, 外用薬のみでの治療が一定数行われており, ガイドラインが十分 に浸透してない可能性も考えられた.

内服薬による治療は, 外用薬のみの治療に比べ患者満足度が高かった。 RGHにおいては 再発を完全に防ぐことは困難であるが, 内服療法を基本とした, 患者自身が積極的に再発 に対処できる治療が活用されると共に，患者の悩みや希望に寄り添った患者指導が行われ るようになることが望まれる。

Key words : 性器ヘルペス (Genital herpes), アンケート調査（Questionnaire survey）, 患者意識（Patients' perception）, 診療実態 (Status of medical practice)

渡辺 大輔 ${ }^{1)}$ Watanabe Daisuke

大須賀 彩 ${ }^{2)}$ Osuga Aya

福田 博章2) Fukuda Hiroaki

菊川 義宣 ${ }^{2}$ Kikukawa Yoshinobu

1) 愛知医科大学医学部 皮膚科学教室

2) マルホ株式会社 メディカルアフェアーズ部

別刷請求先：福田 博章

マルホ株式会社 メディカルアフェアーズ部

テ531-0071 大阪市北区中津1-11-1 中津センタービル

\section{背 景}

性器ヘルペス（genital herpes：GH）は単純へ ルペスウイルス (herpes simplex virus: HSV) の感染により, 性器周辺に痛みを伴う水疮や潰瘍 などの病変を生じる疾患である。初感染後, HSV は知覚神経節に終生潜伏感染し，疲労等に伴う宿 主の免疫低下により再活性化すると再発病変を形 成する。これを再発性性器ヘルペス（recurrent 
genital herpes：RGH）と呼ぶ. 再発の頻度は数 年に1回から毎月のように出現するものまで個人 差がある, 再発病変出現前に, 患部の違和感, 灼 熱感, そう痒等の初期症状を感じることがある.

RGHは他の性感染症や尿路感染症等との鑑別 が必要であるが，本邦では成人の半数以上がHSV に対するIgG抗体が陽性 ${ }^{1)}$ であるため抗体価を用 いた確定診断は困難であり，診断に難渋すること もある. 治療には通常, 内服または外用の抗へル ペスウイルス薬が使用されるが, 特に胵部や子宮 頸部にもウイルスの再活性化部位があることなど から, 外用薬のみの治療は推奨されていない2 ${ }^{2}$. 内服薬では従来の 5 日間投与や，バラシクロビル の再発抑制療法に加え, 近年では初期症状の自覚 後, 速やかに患者判断でファムシクロビルの服薬 を開始できるPatient Initiated Therapy（以下， PIT）が承認され選択肢が広がったが，まだ十分 に浸透していないのが現状である.

一方， RGHの精神面への影響については，一 般に初発時と比較し症状は軽いとされるものの, 病変がプライベートパーツに生じる後ろめたさ, パートナーや家族へ感染させる恐れ等による精神 面や感情面の苦痛が大きい疾患 ${ }^{3)}$ であるため, メ ンタルケアを含めた丁寧な患者指導も重要とされる。 しかし，羞恥心等により患者が積極的に症状を訴え られない場合もあることから，医師に肉体的・精神 的負担が正確に伝わらず，不適切な診断，治療や 患者指導が行われている可能性が否定できない.

本調査では，RGH患者およびRGH患者の診療 機会が多い皮膚科, 婦人科, 泌尿器科の医師を対 象に，患者ニーズおよび診療実態に関するアンケ ート調査を行った。

\section{方 法}

本研究はWebアンケート形式で, 開始前に研究 概要を開示し, 調査対象者の確認により同意を取 得して実施した。調査の実施および結果の集計は エムスリー株式会社が行った（調査期間 患者調 查：2019年12月25日～26日，医師調査：2019年12 月26日～27日). 本研究は, 特定非営利活動法人 皮膚の健康研究機構倫理審査委員会（委員会番
号：19000025）による承認の上，ヘルシンキ宣言 に基づく倫理的原則，「人を対象とする医学研究 に関する倫理指針」（平成26年12月22日，文部科 学省，厚生労働省）および「人を対象とする医学 研究に関する倫理指針ガイダンス」(平成27年2月 9日，文部科学省，厚生労働省）に従って実施した。

\section{1. 調查対象}

\section{1）患者調査}

回答時の年齢が20歳以上であり，過去に $\mathrm{GH}$ と 診断され，過去1年間で1回以上再発している患者 を対象とした。目標回答数は 200 件とした。

\section{2) 医師調查}

主たる勤務施設が皮膚科, 婦人科, 泌尿器科のい ずれかを第一標榜とするクリニックで，直近1年間で ひと月当たり平均 1 人以上のRGH患者を診察してい る医師を対象とした，目標回答数は200件とした。

\section{2. 調査項目}

調査項目の一覧を表1に示した。患者調査では, 内服薬の使用方法について「PIT」を「初期症状が 出た時に，事前に処方された抗ウイルス薬を飲む」,

\section{表1 調査項目}

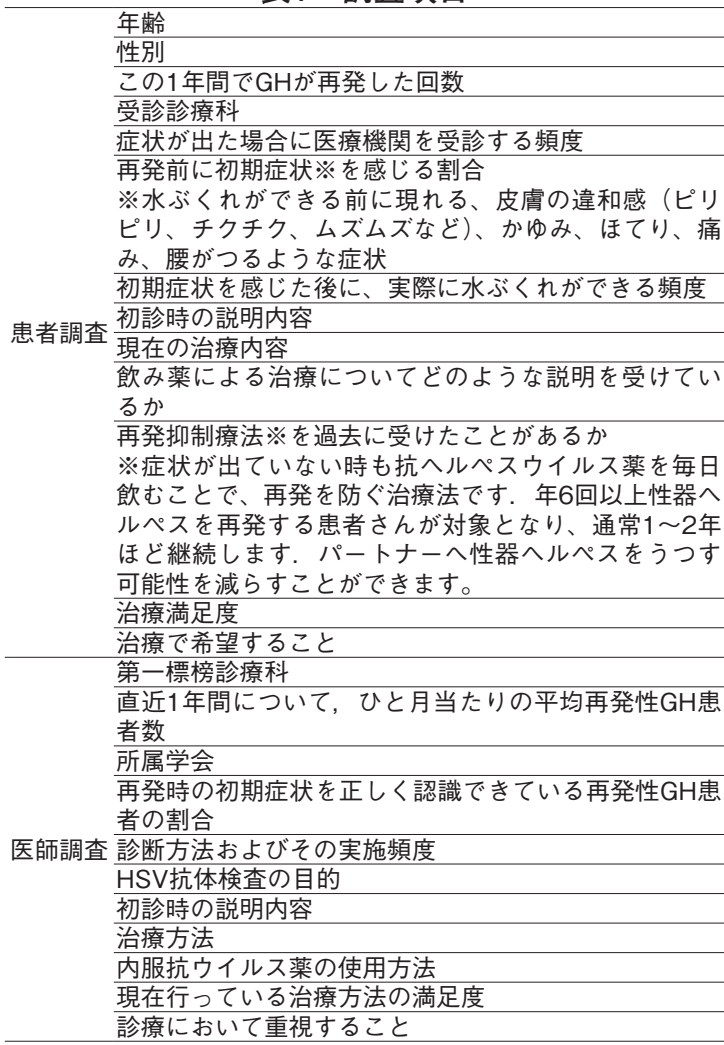


「5日間投与」を「症状が出た後に病院を受診し，処 方される抗ウイルス薬を5日間飲む」,「再発抑制療 法」を「症状が出ていない時も抗ウイルス薬を毎 日飲む」と言い換えた. PITは現在ファムシクロビ ルの先発品のみで承認されているが, 患者調査で は薬剤を限定しなかった。一方, 医師調査におけ る「PIT」はファムシクロビルでの治療に限定した.

\section{結 果}

\section{1. 回答者の背景}

\section{1）患者調査}

232名から回答を得た。内訳は男性が149名 (64.2\%)，女性が83名（35.8\%）であり，女性は30 代，男性は40代が最も多かった。再発頻度が年1 〜2回の患者が79.7\%を占め, 年3〜 5回の患者は $11.2 \%$, 年6回以上再発する患者は $9.1 \%$ ，男女で 傾向の違いはなかった（表2a）.

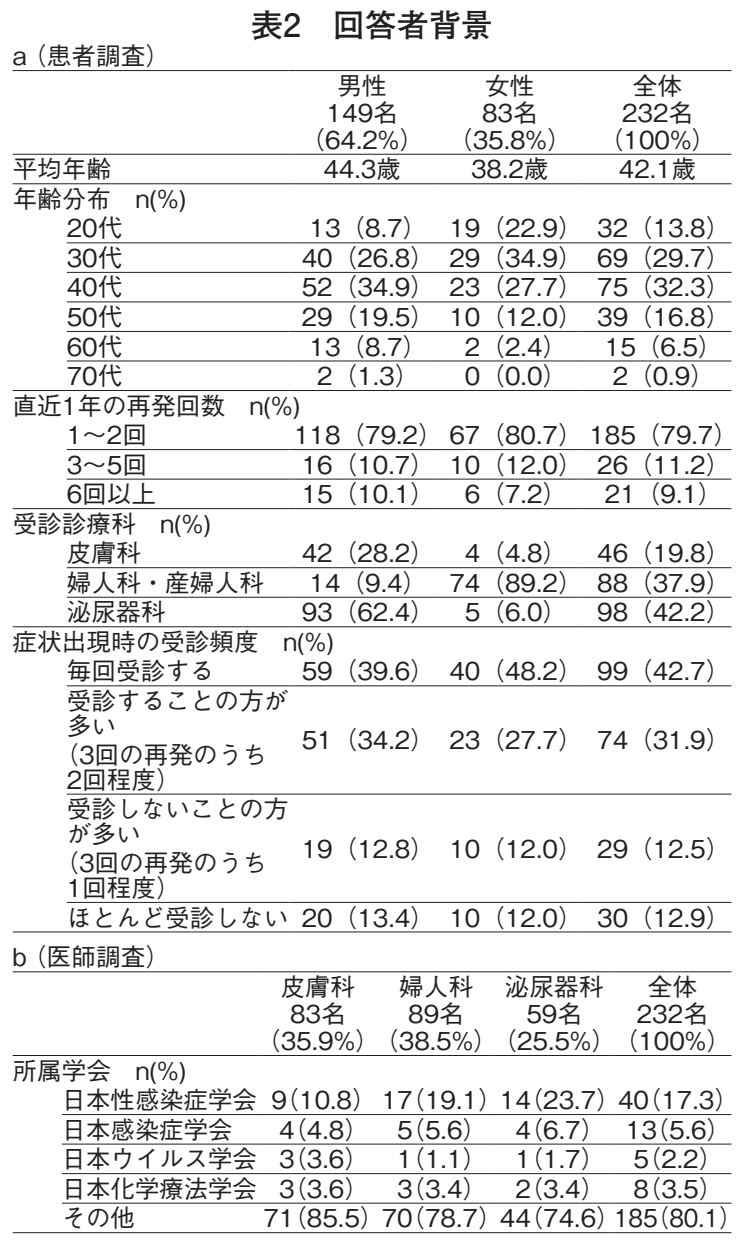

\section{2) 医師調査}

231名から回答を得た。内訳は皮膚科が83名 $(35.9 \%)$ ，婦人科が 89 名 $(38.5 \%)$, 泌尿器科が 59 名（25.5\%）であった。ひ当たりのRGH患者 数の平均は全体で 6.9 人であり, 皮膚科が 9.0 人, 婦人科が 6.5 人, 泌尿器科が 4.4 人であった。

所属学会（複数選択可）は, 日本性感染症学会 が $17.3 \%$, 日本感染症学会が5.6\%, 日本ウイルス学

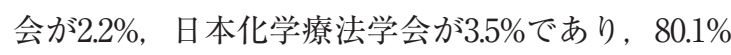
はその他の学会のみに所属していた（表2b).

\section{2. 初期症状}

\section{1）患者調査}

再発前に初期症状を感じる割合について質問し たところ，再発前に初期症状を「毎回感じる」ま たは「感じることのほうが多い」と回答した患者 は, 再発回数が年1 2回，年3〜5回および年 6 回

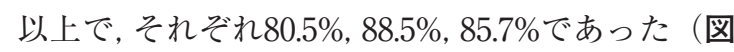
1a）。また，初期症状を感じた後に，実際に水疮 ができる頻度を質問したところ，水疮が「毎回で きる」または「できることのほうが多い」と回答 した患者は,「初期症状を毎回感じる」患者 $(n=107)$ で83.2\%,「感じることのほうが多い」患者 $(n=83)$ で69.9\%,「感じないことのほうが多い」患者 $(n=19)$ で21.1\%であり，初期症状を感じる頻度が高いほ ど，水疮が「毎回できる」または「できることの ほうが多い」と回答する傾向があった。

\section{2) 医師調査}

再発時の初期症状を正しく認識できている RGH患者の割合を，再発回数ごとに質問したと ころ，初期症状を「正しく認識できている」また は「できている患者のほうが多い」と回答した医 師は, 再発回数が年 $1 \sim 2$ 回, 年3〜 5 回および年 6 回以上の患者に対して，それぞれ49.4\%，64.1\%， 74.9\%であり，再発頻度が高い患者ほど，初期症 状を正しく認識できていると判断している傾向に あった（図1b).

\section{3. 受診診療科および受診頻度}

患者が治療のために受診する診療科は，男性は 泌尿器科が $62.4 \%$, 皮膚科が $28.2 \%$, 婦人科が $9.4 \%$ であった，女性は婦人科が $89.2 \%$, 泌尿器科が $6.0 \%$, 皮膚科が $4.8 \%$ あった。症状が出た際の受 
診頻度は，「毎回受診する」が42.7\%，「受診する ことのほうが多い」が31.9\%，「受診しないことの ほうが多い」が12.5\%,「ほとんど受診しない」が 12.9\%であった。

\section{4. 診断}

医師にRGHの診断方法を複数選択可として質 問したところ，「問診」が97.0\%，「視診」が96.1\%， 「HSV抗体検査」が40.7\%,「イムノクロマト法に よる迅速診断キット」が $18.2 \%$,「塗抹標本抗原検 査」が18.2\%,「Tzanckテスト」が16.9\%,「病理 組織検査」が 10.4\%であった.

診断にHSV抗体検査を用いると回答した医師 （n=94）に実施目的を質問したところ，「患部の ウイルスの陽性または陰性確認」が44.7\%,「既往 歴の確認」が26.6\%,「HSVの型判定」が23.4\%で あった。

また, 患部のウイルスの陽性または陰性を判断 する目的で抗体検査を実施すると回答した医師は, 皮膚科が $28.0 \%$, 婦人科が $50.0 \%$, 泌尿器科が $52.6 \%$ あ゙り, 婦人科および泌尿器科で半数を超 えた。

\section{5. 疾患説明（表3）}

1) 患者調査
初診時に受けた説明について質問したところ, 「性行為で感染する病気である」が $36.6 \%$ で最も 多く, 次いで「パートナーの治療も必要である」 が32.3\%，「コンドームを使用する事で性行為によ る感染リスクが下がる」が31.9\%であった.

\section{2) 医師調査}

初診の患者に対する説明内容について質問した ところ，「再発を繰り返す可能性がある」が $77.5 \%$ で最も多く，次いで「抗ウイルス薬の内服により 症状を早期に直すことができる」が70.6\%であった。

その他, 他者への感染リスクや性行為で感染す る疾患であることの説明が多く行われていた。

\section{6. 治療}

\section{1）患者調査}

現在の治療内容は, 内服薬を単独または外用薬 と併用で使用している患者は140名 $(60.3 \%)$, 外 用薬のみ，またはその他で治療している患者が92 名 $(39.7 \%)$ であった.

内服薬使用患者 $(n=140)$ に服用方法について 受けている説明を質問したところ，「症状が出た 後に病院を受診し，処方される抗ウイルス薬を5 日間飲む」が $43.6 \%$ で最も多く，次いで「初期症 状が出た時に, 事前に処方された抗ウイルス薬を

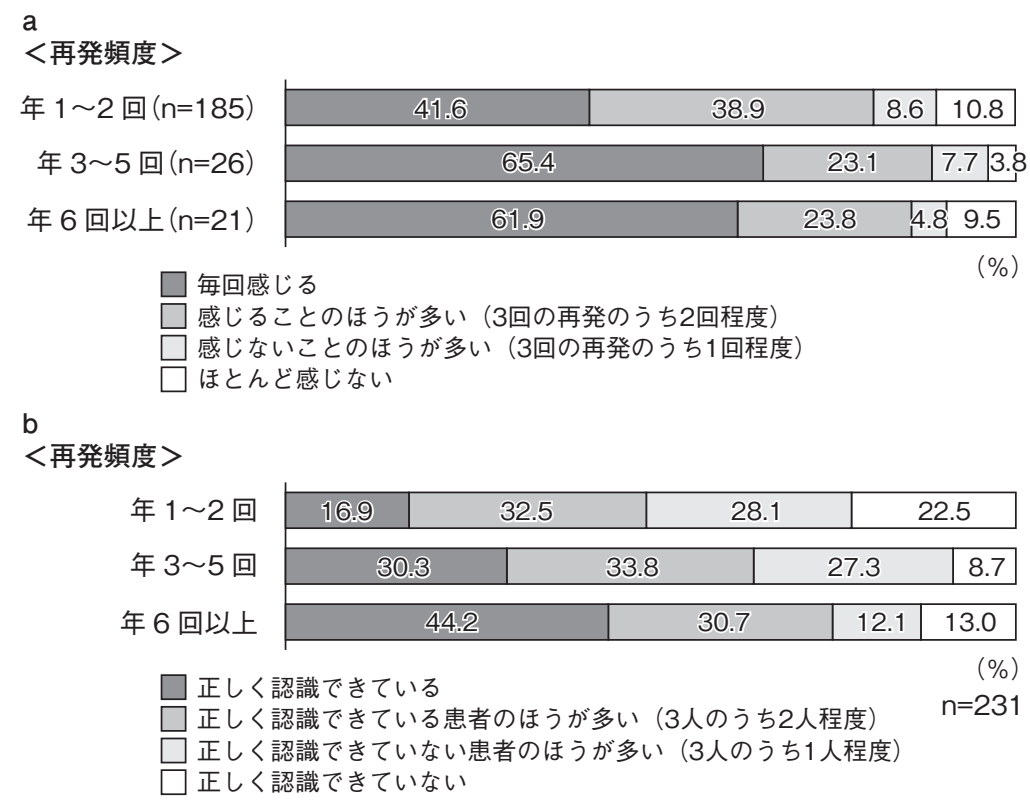

図1 初期症状について

$a$ : 再発前に初期症状を感じる患者の割合 (患者調查),$\quad b$ : 初期症状を正しく認識できている患者の割合（医師調査） 


\section{表3 初診時の説明内容（患者・医師調査）}

\begin{tabular}{|c|c|c|}
\hline & 性行為で感染する病気である & $85(36.6)$ \\
\hline & パートナーの治療も必要である & 75 (32.3) \\
\hline & $\begin{array}{l}\text { コンドームを使用することで、性行為に } \\
\text { よる感染リスクが下がる }\end{array}$ & $74(31.9)$ \\
\hline & $\begin{array}{l}\text { 原因ウイルスは一生体内に潜伏感染し、 } \\
\text { 再発を繰り返す可能性がある }\end{array}$ & $72(31.0)$ \\
\hline & 他の人への感染リスクがある & $71(30.6)$ \\
\hline & $\begin{array}{l}\text { 抗ウイルス薬の内服により治療し、症状を } \\
\text { 早期に治すことができる }\end{array}$ & $64(27.6)$ \\
\hline $\begin{array}{l}\text { 患者調査 } \\
(\mathrm{n}=232)\end{array}$ & $\begin{array}{l}\text { 症状が出たらすぐに治療を開始することが } \\
\text { 重要である }\end{array}$ & 63 \\
\hline & $\begin{array}{l}\text { 再発を防ぐために規則正しい生活を心がけ } \\
\text { る必要がある }\end{array}$ & $52(22.4)$ \\
\hline & $\begin{array}{l}\text { ウイルスの種類によって再発の頻度が異な } \\
\text { る }\end{array}$ & $44(19.0)$ \\
\hline & $\begin{array}{l}\text { 陰部だけでなく慰部（おしり）などにも症 } \\
\text { 状が出ることがある }\end{array}$ & $42(18.1)$ \\
\hline & 感染源の特定は難しい病気である & $32(13.8)$ \\
\hline & $\begin{array}{l}\text { 出産時には新生児への感染に注意しなけれ } \\
\text { ばならない }\end{array}$ & $30(12.9)$ \\
\hline & あてはまるものはない & $16(6.9)$ \\
\hline & $\begin{array}{l}\text { 原因ウイルスは一生体内に潜伏感染し、 } \\
\text { 再発を繰り返す可能性がある }\end{array}$ & $179(77.5)$ \\
\hline & $\begin{array}{l}\text { 抗ウイルス薬の内服により治療し、症状を } \\
\text { 早期に治すこどできる }\end{array}$ & $163(70.6)$ \\
\hline & 他の人への感染リスクがある & $161(69.7)$ \\
\hline & 性行為で感染する病気である & $159(68.8)$ \\
\hline & パートナーの治療も重要である & $138(59.7)$ \\
\hline & $\begin{array}{l}\text { 症状が出たらすぐに治療を開始することが } \\
\text { 重要である }\end{array}$ & $130(56.3)$ \\
\hline $\begin{array}{l}\text { 医師調査 } \\
(\mathrm{n}=231) \\
\mathrm{n}(\%)\end{array}$ & $\begin{array}{l}\text { ) 出産時には新生児への感染に注意しなけれ } \\
\text { ばならない }\end{array}$ & $108(46.8)$ \\
\hline & $\begin{array}{l}\text { 再発を防ぐために規則正しい生活を心がけ } \\
\text { る必要がある }\end{array}$ & $103(44.6)$ \\
\hline & $\begin{array}{l}\text { 陰部だけでなく熨部などにも皮疹が生じる } \\
\text { ことがある }\end{array}$ & $98(42.4)$ \\
\hline & $\begin{array}{l}\text { コンドームを使用することで、性行為によ } \\
\text { る感染リスクが下がる }\end{array}$ & $98(42.4)$ \\
\hline & 感染源の特定は難しい病気である & $82(35.5)$ \\
\hline & ウイルスの型によって再発の頻度が異なる & $47(20.3)$ \\
\hline & あてはまるものはない & $2(0.9)$ \\
\hline
\end{tabular}

飲む」が40.0\%であった。再発抑制療法（症状が 出ていないときも抗ウイルス薬を毎日飲むこと） については, 調查時点で受けている患者は13名 (9.3\%) であったが, 残りの127名のうち70名 (55.5\%) は以前受けていたと回答した.

また，治療内容別に受診頻度を集計したところ， 内服薬を単独または外用薬と併用で使用している 患者, および外用薬のみまたはその他で治療して いる患者のうち，「毎回受診する」と回答した割 合はそれぞれ $53.6 \%$ よび26.1\%であり，内服薬使 用患者の方が高かった（図2a).内服薬使用患者 のうち,「毎回受診する」と回答した患者は,
PIT実施患者で $60.7 \%$, PIT以外の内服方法の患者 では48.8\%であった（図2b).

\section{2）医師調査}

回答者が普段行っているGHの治療方法（複数 選択可）は，「内服薬・外用薬の両方」が $62.8 \%$ と 最も多く,「内服抗ウイルス薬のみ」が $45.5 \%$,「外 用薬のみ」を処方することがあるとした医師は $18.2 \%$ であた。内服薬の使用方法（複数選択可） は，5日間投与が $89.1 \%$, 再発抑制療法が $47.5 \%$, PIT が24.4\%であった。

\section{7. 治療満足度}

\section{1）患者調査}

現在受けている治療に対する満足度を質問した ところ，「満足」を選択した患者は「初期症状が 出た時に，事前に処方された抗ウイルス薬を飲 む」が44.6\%,「症状が出た後に病院を受診し，処 方される抗ウイルス薬を5日間飲む」が31.1\%,「症 状が出ていない時も抗ウイルス薬を毎日飲む」が $32.5 \%$,「外用剤のみの治療」が17.6\%であった（図 3a).なお，「抗ウイルス薬を毎日飲む」につい ては, 再発抑制療法を現在受けている13名に加え 再発抑制療法を以前受けていた70名の計83名が回 答した。

\section{2）医師調査}

現在行っている治療に対する満足度を質問した ところ,「満足」を選択した医師は, PIT が33.3\%, 5 日間投与が $33.5 \%$, 再発抑制療法が $32.4 \%$, 外用

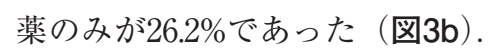

8. 患者が希望することまたは診療で重視すること $\mathrm{GH}$ 診療で患者が希望すること，または医師が

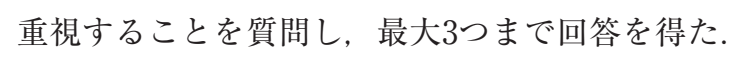
患者が希望することは「早く症状をなくしたい」 が41.8\%で最も多く，次いで「再発をなくしたい」 が38.8\%，「パートナーへの感染を防ぎたい」が 31.0\%であった。医師が重視することは「症状が 出たら早期に受診してもらう」が48.1\%で最も多 く，次いで「ウイルスを完全には除去できず，再 発を繰り返す可能性があることを理解してもら

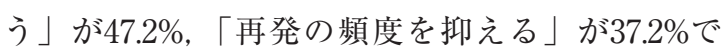
あった．患者と医師の間で差が最も大きかった項 目は「再発をなくす」（患者38.8\%：医師16.9\%) 
a

<治療内容別 全体>

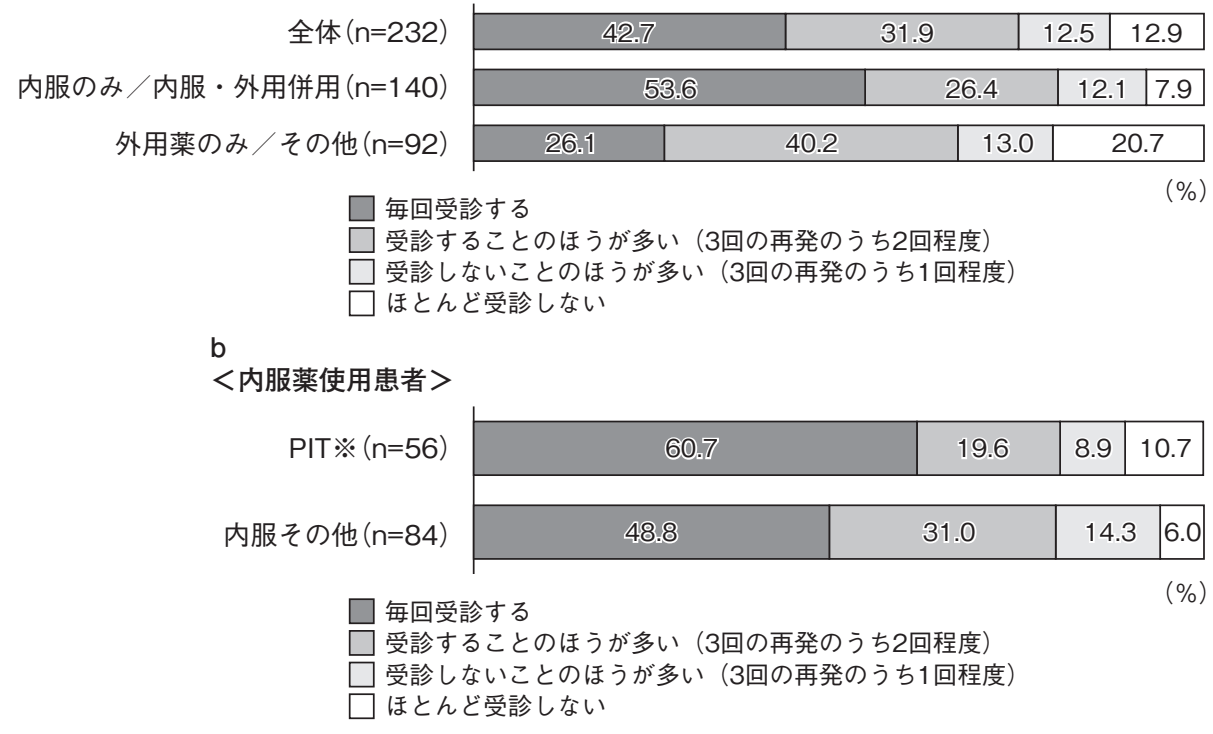

図2 受診頻度（患者調査）

$\mathrm{a}$ : 治療方法別, b : 内服薬の服用方法別.

※「初期症状が出た時に, 事前に処方された抗ウイルス薬を飲む」と指示されている患者

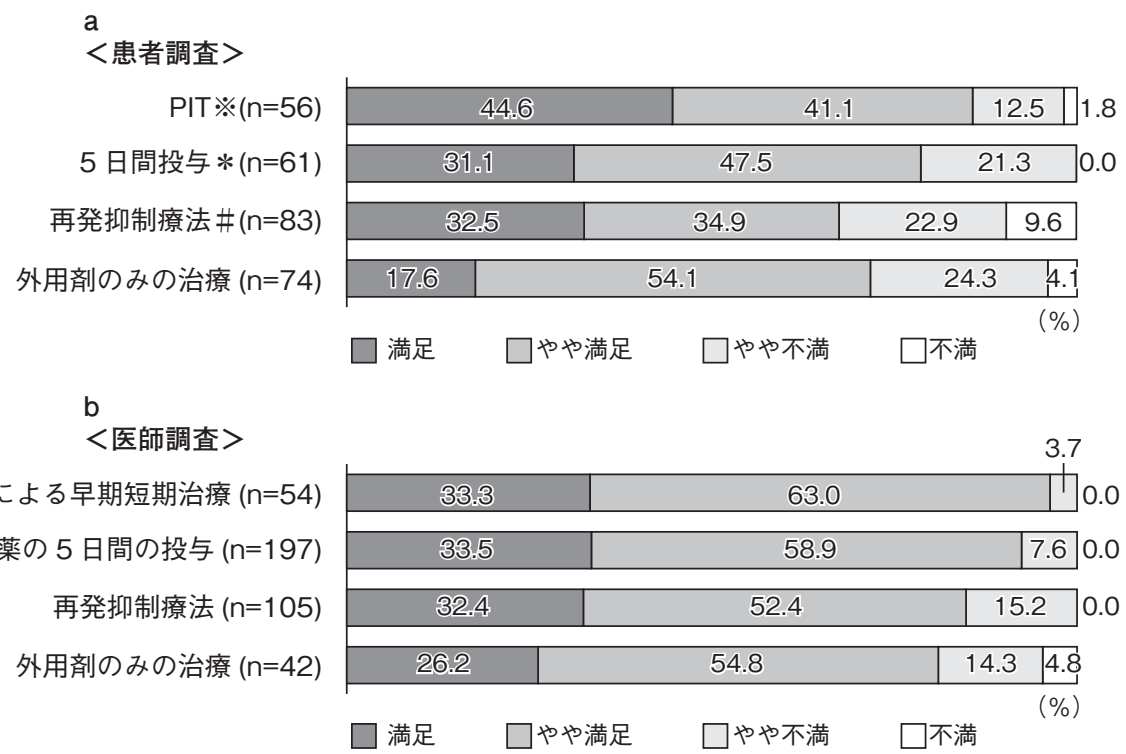

図3 治療満足度について

$a$ ：現在受けている治療に対する満足度 (患者調査), b : 現在行っている治療に対する満足度 (医師調査).

※「初期症状が出た時に，事前に処方された抗ウイルス薬を飲む」と指示されている患者

*「症状が出た後に病院を受診し, 処方される抗ウイルス薬を5日間飲む」と指示されている患者

\#「症状が出ていないときも抗ウイルス薬を毎日飲む」と指示されている患者 
であり, 次いで「治療にかかる費用を抑える」（患 者18.5\%：医師6.1\%）であった（表4）.

\begin{tabular}{|c|c|c|}
\hline \multirow{9}{*}{$\begin{array}{c}\text { 患者調査 } \\
(\mathrm{n}=232) \\
\mathrm{n}(\%)\end{array}$} & 本<证 & $9 /(41.8)$ \\
\hline & 再発をなくしたい & $90(38.8)$ \\
\hline & パートナーへの感染を防ぎたい & $72(31.0)$ \\
\hline & 再発の頻度を抑えたい & $59(25.4)$ \\
\hline & パートナーに知られたくない & $53(22.8)$ \\
\hline & 少しでも症状を軽くしたい & $47(20.3)$ \\
\hline & 治療にかかる費用を抑えたい & $43(18.5)$ \\
\hline & あてはまるものはない & $11(4.7)$ \\
\hline & 精神面でのカウンセリングを受けたい & $10(4.3)$ \\
\hline \multirow{11}{*}{$\begin{array}{c}\text { 医師調査 } \\
(\mathrm{n}=231) \\
\mathrm{n}(\%)\end{array}$} & 症状が出たら早期に受診してもらう & $111(48.1)$ \\
\hline & $\begin{array}{l}\text { ウイルスを完全には除去できず、再発を繰り } \\
\text { 返す可能性があることを理解してもらう }\end{array}$ & $109(47.2)$ \\
\hline & 再発の頻度を抑える & $86(37.2)$ \\
\hline & 他者への感染を防ぐ & $79(34.2)$ \\
\hline & 少しでも症状を軽くする & $65(28.1)$ \\
\hline & パートナーも含めた治療を行う & $59(25.5)$ \\
\hline & 再発をなくす & $39(16.9)$ \\
\hline & 規則正しい生活の指導 & $36(15.6)$ \\
\hline & $\begin{array}{l}\text { 守秘義務を考慮し、パートナーへ知られないよ } \\
\text { う配慮する }\end{array}$ & $18(7.8)$ \\
\hline & 治療にかかる費用を抑える & $14(6.1)$ \\
\hline & 精神面のケアやカウンセリング & $12(5.2)$ \\
\hline
\end{tabular}

\section{考 察}

本研究ではRGH患者およびRGHを診療する医 師を対象に，患者ニーズおよび診療実態について アンケート調査を実施した。

RGHの初期症状に関しては，医師は再発頻度 が高い患者ほど初期症状を正しく認識できている と判断していた。一方で患者は再発頻度を問わず， $80 \%$ 以上患者が3回の再発中 2 回以上は初期症状 を感じると回答した。以上より，患者は少ない再 発頻度であっても医師の印象以上に初期症状を感 じている可能性がある，加えて初期症状を感じる 頻度が高い患者ほど，3回の初期症状のうち2回以 上は水疮ができると回答する割合が高かったこと から，患者は初期症状を一定程度正確に判断でき ていると考える.ファムシクロビルによるPITで は, 治療開始の条件として, 概ね年3回以上の再 発頻度が確認できるとともに，患者が再発の初期 症状（患部の違和感, 灼熱感, そう痒等) を正確 に判断できること等，添付文書記載の条件を満た す必要がある。本結果より，問診時には再発頻度 を確認するだけでなく，初期症状を感じる頻度や
実際に水疮が生じる頻度を確認し，PITが適応と なるか判断することが必要と考える.

受診及び治療の調査では, 症状が出た際に「毎

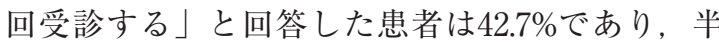
数以上は毎回受診していないことが明らかになっ た．患者の治療意欲を考慮する必要があるが，症 状が出たタイミングでの治療機会を逸している患 者が存在する可能性が示唆された。

医師への診断に関する調査では，44.7\%の医師 が「患部のウイルスの陽性・陰性確認」を目的に 抗体検查を実施すると回答した。一般にHSVの初 感染では不顕性感染のことが多い. GHの初感染 初発例は約7割がHSV-1によるもので，その多く は再発しないとされている 例ではHSV-2が多くを占めるとされる。 久山町研 究においてHSV-2に対するIgG抗体保有率は8.4\% 1) (調查対象者数1244名) 程度と報告されている が，多くが不顕性感染とされ，無自覚のうちに潜 伏感染していることが多いため，抗体検査では感 染の既往の判断はできるものの, 当該病変のRGH 確定診断に用いることは困難である.

また，医師への治療に関する調查では，外用薬 のみを処方することがある医師が $18.2 \%$, 外用薬 のみで治療している患者が $31.9 \% て ゙ あ り ，$ 外用薬 のみでの治療が一定数行われていた，皮疹の経過 や患者希望等により，外用薬の使用は一概に不適 切とは言えない。しかし，外用薬は皮膚局所での 作用しかなく，皮疹の部位によって塗り残しが生 じた場合，早期の改善が期待できない可能性があ る。また，特に女性では臸部や子宮頸部にもウイ ルスの再活性化部位がある ${ }^{2)}$

日本性感染症学会の性感染症診断・治療ガイド ラインや，産婦人科診療ガイドライン ${ }^{4)}$ では, RGHの抗体価測定による現在の感染の証明や, 外用薬のみの治療については推奨されていないが, 今回の結果からガイドラインの内容は十分に周知 されておらず，適切な診断および標準的な治療が 行われていない可能性が考えられた，本調査では 医師の $17.3 \%$ が性感染症学会の会員であったが, 現状を考えると学会員のみならずRGHを診療す る医師に対し，ガイドラインのより一層の周知が 
望まれる。

疾患説明に関する調查では，医師の説明の中で 最も割合の高い「再発を繰り返す可能性がある」 が77.5\%（皮膚科 $73.5 \%$, 婦人科 $78.7 \%$, 泌尿器科 81.3\%）であったのに対して，患者が説明を受け たと認識している割合は $31.0 \%$ （皮膚科 $26.1 \% ，$ 婦 人科 $30.2 \%$, 泌尿器科 $26.5 \%)$ であった。説明を受 けたとする患者が $36.6 \%$ （皮膚科 $30.4 \%$ ，婦人科 $29.5 \%$, 泌尿器科 $45.9 \%$ ） と最も多い「性行為で 感染する病気である」についても医師は68.8\%（皮 虐科 $60.2 \%$, 婦人科 $74.2 \%$, 泌尿器科 $72.9 \%)$ が説 明したと回答している。今回の調査では，患者の 受診科および医師の標榜診療科の内訳に差異があ り，皮膚科を受診した患者および泌尿器科医師の 回答の影響が弱まっている可能性があるが，その 点を考慮しても医師の説明と患者の理解には差異 が認められた，患者による疾患に対する理解は, 患者の治療意欲向上にも寄与すると予想されるた め, 患者説明に対する工夫が必要と考える.

治療法別の受診頻度をみると，3回の再発のう ち2回以上受診すると回答した患者の割合は，外 用薬のみまたはその他の方法で治療している患者 に比べ内服薬で治療している患者で高かった。治 療満足度の調查では,「やや満足」以上を選択し た患者は外用薬に比べ, 内服薬のPIT や5 日間投 与でやや高かった.

外用薬は一度処方を受ければ数回分の再発に対 応できるため単純に比較はできないが, 内服薬に より早期に効果を実感し治療意欲が高まることで, 受診頻度が向上する可能性が示唆された．さらに, PIT実施患者では「毎回受診する」割合が $60.7 \%$ と, 他の内服方法の患者（48.8\%）に比べ高かった。 再発した曜日・時間帯によっては早期受診が困難 な場合も多いが，PITは患者自身の判断で治療を 開始できるだけでなく都合の良い夕イミングで事 前に受診し処方を受けられるため, 医療機関の受 診に伴う負担が大きく軽減され, 受診頻度が高ま った可能性がある.

RGH診療で患者が希望することおよび医師が 重視することの調査では，医師と患者の意識の乘
離が最も大きい項目は「再発をなくす」（医師 16.9\%：患者38.8\%）であった。疾患説明の調査で も明らかになったように，医師から説明される内 容が患者の記憶に定着せず, 十分な疾患理解につ ながっていない可能性がある。したがって，この ことを念頭に患者に説明する必要があると考える.

なお，今回の調査では回答者の6割が男性，8割 が年1 2回の再発であった。疫学的に男女比は 1:2 2 と報告されており実臨床と男女比が異なる が，これは女性のほうがGHに関するアンケート 回答する上での羞恥心や忌避感が強かった可能性 が考えられる。また皮膚科の医療機関を対象にし た調査 ${ }^{6)}$ では，年1～2回の患者は約 $20 \%$ であると 報告されていること，一般的に女性患者の方が重 症度が高くなる傾向があることなどから, 今回の 調査では再発時の症状や再発頻度が軽い患者が多 かった可能性があることに留意する必要がある.

本調査の結果, 現在のRGHの診断, 治療およ び患者指導における課題が明らかとなった. $\mathrm{RGH}$ は患者のQOLを著しく障害することが知られて いるにもかかわらず, 必要な情報が患者に十分伝 わっているとは言えず, 診断や治療の選択も一部 でエビデンスやガイドラインに基づいたものが行 われていない可能性が示唆された，再発を完全に 防ぐことは現在の医学では難しいものの,「再発 をなくしたい」,「早く症状をなくしたい」という 患者希望を叶えQOLを高めるため, 我々は最善 の策を講じる必要がある。疾患による患者の負担 を最大限にコントロールするためには, 内服治療 を基本として，再発頻度や患者満足度に応じた治 療法を活用することが有用と考えられる。また， 病気と上手に付き合うことができると説明する等, 患者の心情に配慮した丁寧な指導を行うことで, 患者の治療満足度の高まりが期待されると考える.

\section{[利益相反 $]$}

本研究の実施及び本論文作成にかかわる費用はマルホ株式会社 が負担した。渡辺大輔はマルホ株式会社より, 講演料, 原稿料 を受けている。調查の実施及び調查結果の集計はエムスリー株 式会社に委託した。大須賀彩, 福田博章, 菊川義宣はマルホ株 式会社の社員である. 


\section{文 献}

1 ) Doi Y et al: Seroprevalence of herpes simplex virus 1 and 2 in a population-based cohort in Japan. J Epidemiol 2009; 19: 56-62.

2 ）一般社団法人日本性感染症学会：第2部4 性 器ヘルペス; 日本性感染症学会編, 性感染症 診断・治療ガイドライン 2020 , 第1版, 診断と 治療社, 東京, 2020, 65-70.

3 ) 川島 眞: 再発型単純疮疹患者の患者背景お よびQOLに関するアンケート調查. 臨床医薬
2013; 29: 137-149.

4 ）公益社団法人日本産科婦人科学会, 日本産婦 人科学会 : CQ103 性器ヘルペスの診断と治 療は? ; 産婦人科診療ガイドライン 婦人科 外来編 2020 , 第 1 版, 日本産科婦人科学会事務 局, 東京, 2020, 6-8.

5 ）松尾光馬：ヘルペス性疾患に対する診断と治 療. 耳展 2019; 62 : 134-143.

6 ）永井宏ほか: 皮膚科における外陰へルペスの 現況と多因子的解析. 日性感染症会誌 1998; 9: 78-81.

\title{
A questionnaire survey on the current status of treatment of patients with recurrent genital herpes-Needs of patients and actual clinical practice by doctors specialized in dermatology, gynecology, or urology
}

\author{
Daisuke Watanabe $^{1)}$, Aya Osuga ${ }^{2)}$, Hiroaki Fukuda ${ }^{2)}$, Yoshinobu Kikukawa ${ }^{2)}$ \\ 1 ) Department of Dermatology, Aichi Medical University \\ 2) Medical Affairs Department, Maruho Co, Ltd.
}

We conducted a questionnaire survey to investigate the needs of patients with recurrent genital herpes (RGH) and actual clinical practice by doctors.

The respondents comprised 232 patients with RGH and 231 doctors, including dermatologists, gynecologists/ obstetricians, and urologists. Among patients who replied to the survey, the male/female ratio was $6: 4$, and $80 \%$ of the patients had 1-2 recurrences per year. While $60 \%$ of all patients used oral antiviral drugs alone or in combination with topical antiviral agents, $30 \%$ replied that they were treated with topical antiviral drugs (hereinafter, topical drugs) alone. The proportion of patients who rated the current treatment "satisfactory" was $44.6 \%$ for patient-initiated therapy (PIT), 31.1\% for 5-day administration, 32.5\% for suppressive therapy, and $17.6 \%$ for topical drugs alone.

Among doctors who replied that they use viral antibody tests for diagnosis, more than half of the gynecologists/obstetricians or urologists replied that they perform antibody tests to determine the presence/ absence of the virus in rashes at the patients' visits. What patients and doctors considered important in RGH care differed greatly.

The item that showed the largest difference was "prevention of recurrence" (38.8\% in the patients and 16.9\% in the doctors).

The results of this survey showed that, although the main therapy was oral therapy recommended by practice guidelines by the Japanese Society for Sexually Transmitted Infections and other academic societies, a certain number of patients are treated with topical drugs alone, suggesting the possibility that the guidelines have not been adopted well.

Treatment with oral antiviral drugs had higher patient satisfaction than that with topical drugs alone. Although preventing recurrence of RGH completely is difficult, it is desirable to provide basically oral treatments with which patients can handle recurrence proactively, and to instruct patients with consideration of their worries and wishes. 